\title{
Mediated relationship: menakar hubungan organisasi-publik dalam akun Instagram resmi perusahaan telekomunikasi
}

\author{
Syaifa Tania \\ Universitas Gadjah Mada, Yogyakarta, Indonesia
}

\begin{abstract}
ABSTRAK
Orientasi utama dalam praktik komunikasi korporat adalah kemampuan humas untuk mengelola hubungan organisasi dan publik yang efektif. Selaras dengan peran humas untuk menjalankan fungsi komunikasi publik yang bersifat simetris dua arah, kehadiran media baru dianggap sebagai media komunikasi yang potensial untuk mewujudkan fungsi tersebut. Seiring dengan perkembangan tren media baru, Instagram menjadi salah satu media komunikasi yang banyak digunakan organisasi. Meskipun demikian, sebagai platform media sosial berbasis visual, Instagram belum sepenuhnya mampu dipraktikkan untuk membangun relasi dialogis antara organisasi dan publik. Studi ini berupaya menakar hubungan organisasi dan publik yang ditampilkan di tiga akun Instagram resmi perusahaan penyedia jasa telekomunikasi seluler Indonesia. Metode yang diterapkan dalam studi ini adalah analisis isi kuantitatif dengan menggunakan empat dimensi hubungan dan dua bentuk luaran hubungan sebagai kerangka konseptualnya. Hasil studi menunjukkan bahwa terdapat perbedaan persepsi antara organisasi dan publik dalam memaknai Instagram sebagai media komunikasi korporat. Organisasi cenderung menggunakan Instagram sebagai media pembentuk citra, sementara publik memosisikan Instagram sebagai media pelayanan keluhan konsumen seperti kanal lainnya. Secara umum, tarikan atas simpulan utama menunjukkan bahwa tidak ada formula tunggal dalam praktik penggunaan media sosial di antara organisasi. Meskipun ketiga organisasi bergerak di bidang industri yang sama, namun hal tersebut tidak serta merta membuat ketiganya menerapkan pola serupa dalam memanfaatkan media sosial sebagai kanal komunikasi untuk menjalin hubungan organisasi dan publik.
\end{abstract}

Kata-kata Kunci: Hubungan organisasi dan publik; komunikasi korporat; Instagram; media baru; digital PR

\section{Mediated relationship: assessing organization-public relationship in telecommunication service provider official Instagram accounts}

\begin{abstract}
The primary orientation in the practice of corporate communication is the ability to maintain a good relationship between the organization and the public. Along with the role of corporate communication to carry two-ways mutually beneficial relationships with the public, new media emerges as a promising medium to fulfill the need. Organizational use of popular social media platforms also emerges as a trend in order to create brand presence and building a relationship with their public. Instagram, as one of the most popular platforms today, is no exception. However, as a visual-based platform, Instagram may not be entirely suitable to be used to build a dialogic relationship between the organization and the public. The purpose of this study is aimed to measure organization and public relationships, as shown in three official Instagram accounts of Indonesian top three telecommunication service provider companies. By using quantitative content analysis, this study discovered that there is a different perception of the role of Instagram between organizations and the public. The organization tends to put the role of Instagram as an image-building medium, while the public considers Instagram as a customer care medium. Thus, it caused by the effectivity of mediated relationships. The findings also indicate that different organizations from the same field of an industry may use the same social media platform differently. The different practice of using Instagram among three telecommunication service provider companies is provided in this study.
\end{abstract}

Keywords: Organization public relationship; corporate communication; Instagram; new media; digital PR

Korespondensi: Syaifa Tania, S.IP., M.A. Departemen Ilmu Komunikasi Fakultas Ilmu Sosial dan Ilmu Politik Universitas Gadjah Mada. Jalan Sosio Yustisia No.2, Bulaksumur, Caturtunggal, Depok, Sleman, Yogyakarta 55281.E-mail: syaifa.tania@ugm.ac.id 


\section{PENDAHULUAN}

Perkembangan landskap media baru menawarkan pilihan kanal yang lebih beragam dalam memediasi proses komunikasi antara organisasi dan publik. Media baru diyakini mampu memangkas waktu, sehingga menempatkan aspek kecepatan dalam pengelolaan aktivitas komunikasi pemasaran pada posisi utama. Meskipun demikian, aspek kecepatan dan otomatisasi yang menjadi penciri karakter "mesin" tidak serta merta cukup sebagai modal dalam menjalin relasi. Personalisasi sebagai ciri khas nilai kemanusiaan yang melekat dalam interaksi dialogis antara organisasi dan publik tetap menjadi unsur signifikan.

Kajian tentang hubungan organisasi dan publik menjadi topik yang menarik dalam satu dekade terakhir. Meskipun demikian, seluruh kajian sejatinya berakar pada perspektif relasional yang mengacu pada model komunikasi simetris dua arah (Grunig, 2009). Perspektif relasional tersebut sejalan pula dengan definisi konseptual peran public relations dalam organisasi untuk membangun hubungan dialogis yang saling menguntungkan bagi organisasi dan publik (Cutlip, Center, \& Broom, 2009). Di antara beragam kanal media baru, media sosial cenderung diposisikan oleh sebagian besar organisasi sebagai kanal utama untuk menjalin hubungan dengan publik.
Pemosisian media sosial sebagai kanal komunikasi utama untuk menjalin hubungan dengan publik tidak lepas dari kesadaran organisasi atas signifikansi dan peluang yang dimiliki oleh media sosial. Dalam perspektif organisasi, karakteristik fitur yang dimiliki media sosial diyakini mampu memberikan keuntungan karena mempermudah proses komunikasi, interaksi, serta memperbesar peluang kolaborasi dengan publik (J.Jussilaa, Kärkkäinena, \& HeliAramo-Immonenb, 2014). Media sosial memungkinkan organisasi untuk dapat berkomunikasi dengan publik (direct end-consumer) dalam konteks real time dengan biaya yang jauh lebih rendah dan efisien dibandingkan menggunakan media komunikasi pemasaran lain (Jahn \& Nielsen, 2011). Di sisi lain, dalam perspektif publik media sosial telah menjadi media informasi utama dalam proses pencarian informasi tentang brand atau produk, bahkan melampaui corporate website (Men \& Tsai, 2014). Lebih lanjut, media sosial diyakini pula telah mampu mendorong publik untuk lebih berdaya seiring lahirnya konsep usercentered social media yang memungkinkan publik untuk menjadi kreator konten yang dapat berpartisipasi aktif dalam berinteraksi dengan organisasi melalui fitur likes, comments dan share dalam lingkup jejaring sosialnya (Muntinga, Moorman, \& Smit, 2011).

Potensi media sosial untuk mengakomodasi 
interaksi antara organisasi dan publik mendorong kehadiran fisik yang sebelumnya menjadi prekondisi mutlak atas proses komunikasi interpersonal tidak lagi diperlukan. Melalui akun resmi yang dimiliki oleh organisasi di media sosial (official account), publik dan organisasi dapat saling terhubung secara virtual. Selaras dengan gagasan Grunig tentang model komunikasi simetris dua arah, idealnya media sosial memungkinkan proses komunikasi yang terjadi antara organisasi dan publik berjalan linier, sekaligus menampakkan kelindan peran antara teknologi dan manusia (human) (Grunig, 2009). Dalam konteks hubungan antara organisasi dan publik, media sosial sebagai artefak teknologi menawarkan segenap fitur yang idealnya memungkinkan efektivitas pengelolaan proses komunikasi antara organisasi dan publik terakomodasi dengan baik. Sementara itu, manusia (human) berperan vital dalam memberikan tekanan pada nilai-nilai humanitas yang perlu ditekankan dalam proses interaksi.

Penggunaan media sosial sebagai media komunikasi dilakukan pula oleh industri penyedia jasa layanan telekomunikasi (telecommunication service provider). Sebagai bidang industri yang lekat dan bergerak di bidang teknologi, hampir seluruh perusahaan penyedia jasa layananan telekomunikasi menggunakan media sosial sebagai kanal komunikasi untuk mengelola hubungan dengan publik. Sebelum platform media sosial hadir dan berkembang, upaya organisasi untuk berinteraksi dengan publik ditumpukan pada layanan konsumen (customer care service) berbasis telepon (phone call). Seiring perkembangan media sosial, fungsi ini diambil alih oleh administrator di akun media sosial resmi organisasi sehingga seluruh keluhan atau pertanyaan publik dapat direspon secara lebih efektif dan efisien. Lebih lanjut, selaras dengan karakteristik industri yang memungkinkan seluruh aktivitas layanan konsumen diselesaikan hingga tuntas menggunakan perangkat teknologi tanpa membutuhkan kehadiran fisik konsumen, maka media sosial cenderung diposisikan sebagai garda depan oleh perusahaan.

Di antara berbagai kanal media sosial yang ada, Instagram menjadi kanal populer yang banyak diakses para pengguna media baru di Indonesia. Proses instant sharing momen keseharian pengguna dalam bentuk visual menjadi kunci utama yang mendorong popularitas Instagram. Kondisi ini sejalan dengan gagasan Schill yang menyebutkan adanya perubahan pola dalam proses komunikasi di media digital berbasis visual (Schill, 2012). Meskipun demikian, pergeseran pola akses informasi mendorong urgensi untuk turut serta menempatkan Instagram dalam ekologi media sosial ketika mengkaji isu komunikasi di media 
baru (Russmann \& Svensson, 2016).

Penggunaan Instagram sebagai salah satu media komunikasi korporat memantik diskusi berkaitan dengan penerapan strategisnya (strategic implementation) dalam memediasi hubungan organisasi dan publik. Sebagai media komunikasi berbasis visual, proses dialogis yang tercipta antara organisasi dan publik selaiknya akan memiliki pola berbeda dibandingkan media komunikasi berbasis tekstual. Dalam media sosial berbasis tekstual takaran hubungan organisasi dan publik dapat ditekankan pada narasi tekstual (focused on written words) sementara dalam media sosial berbasis visual pendekatan serupa tidak sepenuhnya dapat diterapkan. Dalam media sosial berbasis visual relasi yang terbentuk antara organisasi dan publik tidak bisa sematamata dilihat hanya pada aspek visualisasinya saja, melainkan juga pada interaktivitas yang tercermin dalam interaksi antara organisasi dan publik misalnya melalui fitur komentar.

Upaya menakar hubungan organisasi dan publik secara konseptual digagas oleh Hon dan Grunig yang menyebutkan enam keluaran hubungan yaitu mutualitas kontrol (control mutuality), kepercayaan (trust), komitmen (commitment), kepuasan (satisfaction), relasi komunal (communal relationship), dan relasi transaksional (exchange relationship). Sejumlah studi dengan menggunakan konsep ini telah dilakukan setidaknya dalam kurun lima tahun terakhir. H. Edman mengkaji hubungan antara organisasi dan publik dengan menganalisis 47 akun Twitter perusahaan di Amerika (Edman, 2010). Studi tersebut berupaya memahami bagaimana perusahaan menggunakan Twitter sebagai media komunikasi yang digunakan perusahaan untuk membangun hubungan dengan publiknya (Edman, 2010). Kajian lain dilakukan oleh S. Tania yang menakar hubungan organisasi dan publik pada sejumlah perusahaan di tiga bidang industri di Indonesia sebagaimana dicerminkan di akun Twitter resmi masing-masing organisasi (Tania, 2015). Hasil studi ini menunjukkan bahwa organisasi secara aktif menggunakan Twitter sebagai media komunikasi dengan publik, meski proses komunikasi yang dilakukan cenderung masih bersifat responsif dan transaksional.

Dua studi terdahulu yang dilakukan dalam meskipun mengambil objek dan lingkup berbeda, namun keduanya mengambil lokus yang sama yaitu Twitter sebagai media komunikasi berbasis tekstual. Sementara itu, media komunikasi berbasis visual seperti Instagram yang saat ini dianggap sebagai platform media sosial paling populer justru belum dikaji secara mendalam. Secara umum, perbedaan karakter antara budaya tekstual dan visual seyogyanya menuntut adanya pola komunikasi yang berbeda, serta bukan tidak 
mungkin akan menghasilkan efek komunikasi yang berbeda pula. Akibatnya, proses komunikasi yang terjadi di kedua medium tidak bisa disamaratakan.

Dalam bidang studi hubungan masyarakat, Instagram mungkin telah menjadi lokus media komunikasi yang banyak dikaji. Meskipun demikian, fokus kajian tentang hubungan organisasi dan publik di Instagram cenderung belum banyak didiskusikan. Menurut Smith dan Sanderson fokus kajian terhadap Instagram cenderung didominasi oleh studi pengguna Instagram dan mengkaji isu tentang presentasi dan citra diri (Smith \& Sanderson, 2015). Penelitian lain mengemukakan bahwa salah satu motif penggunaan media sosial sebagai bentuk ekspresi diri (Lee, Moon, Lee, \& Sung, 2015). Sementara itu, kajian tentang penggunaan Instagram dari perspektif relasional organisasi masih jarang didiskusikan (Richardson, Ganz, \& Vallone, 2014). Penelitian ini berupaya untuk mengisi gap kajian dengan memfokuskan objek studi pada Instagram sebagai media sosial berbasis visual yang memiliki karakter berbeda dengan tekstual dalam memahami bagaimana organisasi menjalin relasi dengan publiknya di kanal media baru. Secara khusus, penelitian ini bertujuan untuk memetakan bentuk hubungan organisasi dan publik yang nampak dan termanifestasi dalam unggahan di akun Instagram resmi organisasi.
Menyadari bahwa keseimbangan relasi hanya dapat terjadi apabila organisasi dan publik sama-sama memiliki kuasa yang setara dalam mengelola proses komunikasi dan interaksi, skeptisisme terhadap aspek kuasa publik muncul. Faktanya, relasi antara organisasi dan publik tidak pernah sepenuhnya berjalan seimbang. Proses komunikasi yang dilakukan organisasi dijalankan secara terorganisir, sedangkan publik relatif tersebar sehingga proses komunikasi dijalankan secara individual. Selain itu, ruang komunikasi yang dimiliki oleh publik untuk berkomunikasi tidak selalu berbanding lurus dengan respon organisasi. Pesan yang disampaikan publik kepada organisasi dapat diabaikan karena ketiadaan keseimbangan kuasa dalam mengontrol proses komunikasi antara organisasi dan publik.

Pada akhirnya, gagasan tentang keseimbangan relasi antara organisasi dan publik di media baru kiranya perlu didiskusikan ulang. Media sosial sebagai media komunikasi populer saat ini memang benar memiliki potensi yang besar dalam memediasi hubungan organisasi dan publik. Meskipun demikian, catatan penting perlu dititikberatkan pada aspek penerapan media sosial itu sendiri oleh organisasi untuk membangun hubungan simetris dua arah dengan publik.

\section{METODE PENELITIAN}


Hubungan organisasi dan publik dalam studi ini akan ditelaah melalui proses interaksi di antara keduanya yang ditunjukkan dalam akun resmi Instagram organisasi. Akibatnya, meskipun studi ini mengambil lokus pada media komunikasi berbasis visual namun aspek visualisasi seperti simbol yang kerap dititikberatkan pada metode semiotika tidak diterapkan dalam studi ini. Unit analisis yang diterapkan dalam studi ini adalah teks yang disampaikan dalam unggahan visual dan/atau audio visual (post), caption, serta komentar yang disampaikan publik di unggahan tersebut. Pada prinsipnya, interaksi yang termanifestasi dalam bentuk tekstual menjadi fokus yang dikaji dalam studi ini.

Data yang dikaji dalam studi ini bersifat manifes dan empiris. Pendekatan kuantitatif diterapkan sebagai basis metodologis untuk memahami objek studi. Metode yang diterapkan dalam studi ini adalah metode analisis isi kuantitatif. Karakteristik metode analisis isi kuantitatif dianggap tepat untuk mengeksplorasi konten media yang bersifat manifes, serta memungkinkan untuk mengkaji karakteristik konten komunikasi dan menarik simpulan tentang peran komunikator.

Teknik pengumpulan data dilakukan dengan menggunakan lembar pengodingan (coding sheet). Instrumen coding sheet terbagi menjadi dua bagian utama. Pada bagian pertama coding sheet instrumen disusun dengan tujuan untuk merekam hubungan organisasi dan publik. Indikator yang digunakan pada bagian ini merujuk pada lima dimensi hubungan organisasi dan publik yang dirumuskan meliputi mutualitas kontrol, kepercayaan, kepuasan, komitmen, serta bentuk luaran dari hubungan tersebut.

Selanjutnya, pada bagian kedua coding sheet disusun dengan instrumen yang merekam interaktivitas relasi antara organisasi dan publik sebagaimana tercermin dalam konten unggahan di Instagram. Indikator yang digunakan pada bagian ini meliputi keberadaan interaktivitas antara kedua pihak, bentuk interaksi yang terjadi, tonalitas, serta resiprositas yang muncul.

Studi dilakukan terhadap tiga akun Instagram resmi organisasi penyedia jasa layanan telekomunikasi seluler yaitu@myXL, @indosat,dan@telkomsel. Pemilihan ketiga akun didasarkan pada pertimbangan bahwa ketiganya merupakan perusahaan penyedia jasa layanan telekomunikasi seluler terbesar di Indonesia. Selain itu, ketiga akun memiliki jumlah pengikut (follower) yang besar dibandingkan akun perusahaan lain di bidang yang sama.

Rentang periode pengambilan data dalam penelitian ini ditetapkan selama empat bulan, sepanjang kuartal pertama tahun 2019 (bulan Januari-April 2019). Populasi dalam penelitian 
ini yaitu konten unggahan (post) yang diunggah oleh ketiga akun pada rentang waktu tersebut (n =174). Dalam studi ini tidak dilakukan sampling melainkan mengolah data seluruh populasi (sensus) didasarkan pada pertimbangan akan masih memungkinkannya seluruh data dalam jumlah tersebut diolah dan dianalisis.

Adapun teknik analisis deskriptif menjadi teknik analisis data utama yang diterapkan dalam penelitian ini. Analisis deskriptif digunakan untuk melihat distribusi frekuensi sehingga dapat dipetakan kecenderungan yang menonojol untuk selanjutnya data tersebut dapat dianalisis dan dimaknai oleh peneliti.

\section{HASIL DAN PEMBAHASAN}

Popularitas media sosial berbasis visual telah menarik minat banyak pengguna media baru hingga akhirnya turut mendorong sejumlah pelaku industri untuk mengadopsinya sebagai salah satu kanal komunikasi pemasaran. Paparan tentang hasil pengukuran mediated relationship yang dibangun oleh organisasi di bidang industri penyedia jasa layanan telekomunikasi seluler ditakar dari enam dimensi yaitu mutualitas kontrol, kepercayaan, kepuasan, komitmen, serta dua bentuk keluaran hubungan transaksional dan komunal. Dari keenam dimensi ini dapat ditarik simpulan akan kecenderungan yang dicerminkan masing-masing dimensi, sekaligus membandingkan penerapannya di antara ketiga organisasi yang menjadi objek studi ini. Pada muaranya, analisis terhadap kecenderungan yang ditunjukkan pada hasil olah data setiap dimensi merujuk pada diskusi tentang relasi antara organisasi dan publik di media sosial. Bagian ini memaparkan tentang diskusi mengenai apakah optimisme terhadap media sosial sebagai media yang mampu mewujudkan relasi simetris dua arah benar-benar dapat diwujudkan. Selain itu, diskusi merujuk pula pada diskusi mengenai apakah organisasiorganisasi dalam bidang industri yang sama akan cenderung menerapkan pola yang serupa pula dalam memanfaatkan media sosial sebagai media komunikasi untuk menjalin hubungan dengan publik. Terakhir, diskusi merujuk pula pada gagasan tentang konsep omnichannel yang memberikan peta tentang pemosisian fungsi ragam kanal media sosial yang dimiliki organisasi untuk menjalankan komunikasi dengan publik.

Takaran hubungan antara organisasi dan publik dipahami dengan memetakan lima dimensi hubungan yaitu mutualitas kontrol, kepercayaan, kepuasan, komitmen, serta bentuk luaran hubungan (Hon \& Grunig, 1999). Dimensi mutualitas kontrol berupaya memahami keseimbangan kuasa yang dimiliki oleh organisasi dan publik di dalam hubungan yang terjadi. Idealnya, baik publik maupun organisasi sama-sama memiliki kuasa yang 
setara dalam mengelola proses komunikasi dan interaksi di antara keduanya.

Mutualitas kontrol sebagai sebuah prasyarat yang mengindikasikan keseimbangan kuasa antara organisasi dan publik dalam mengelola proses komunikasi dan interaksi di antara keduanya masih sangat rendah. Dari seluruh konten unggahan dari ketiga akun yang dikaji dalam studi ini, 71\% masih belum menunjukkan adanya kesetaraan kuasa antara organisasi dan publik. Proses komunikasi cenderung masih didominasi oleh organisasi yang diindikasikan dari arah komunikasi yang terjadi. Selain itu, organisasi masih belum memberikan ruang dan kuasa yang cukup besar bagi publik untuk turut mengontrol proses komunikasi dan interaksi yang terjadi.

Di tengah rendahnya mutualitas kontrol antara organisasi dan publik, terdapat 29\% konten unggahan yang mencerminkan adanya dimensi mutualitas kontrol. Bentuk mutualitas kontrol diindikasikan dalam beragam bentuk seperti membalas pertanyaan, membalas keluhan, mention followers, atau kombinasi di antaranya.

Gambar 1 menunjukkan tentang keragaman bentuk mutualitas kontrol yang termanifestasi di akun Instagram resmi ketiga organisasi. Data di atas secara jelas menunjukkan adanya perbedaan pola penerapan dimensi mutualitas kontrol di antara ketiga industri yang bergerak di bidang serupa. Bentuk mutualitas kontrol yang ditampilkan di akun@myXL cenderung didominasi oleh dialog yang terjadi karena organisasi membalas pertanyaan publik yang disampaikan di akun mereka. Sementara

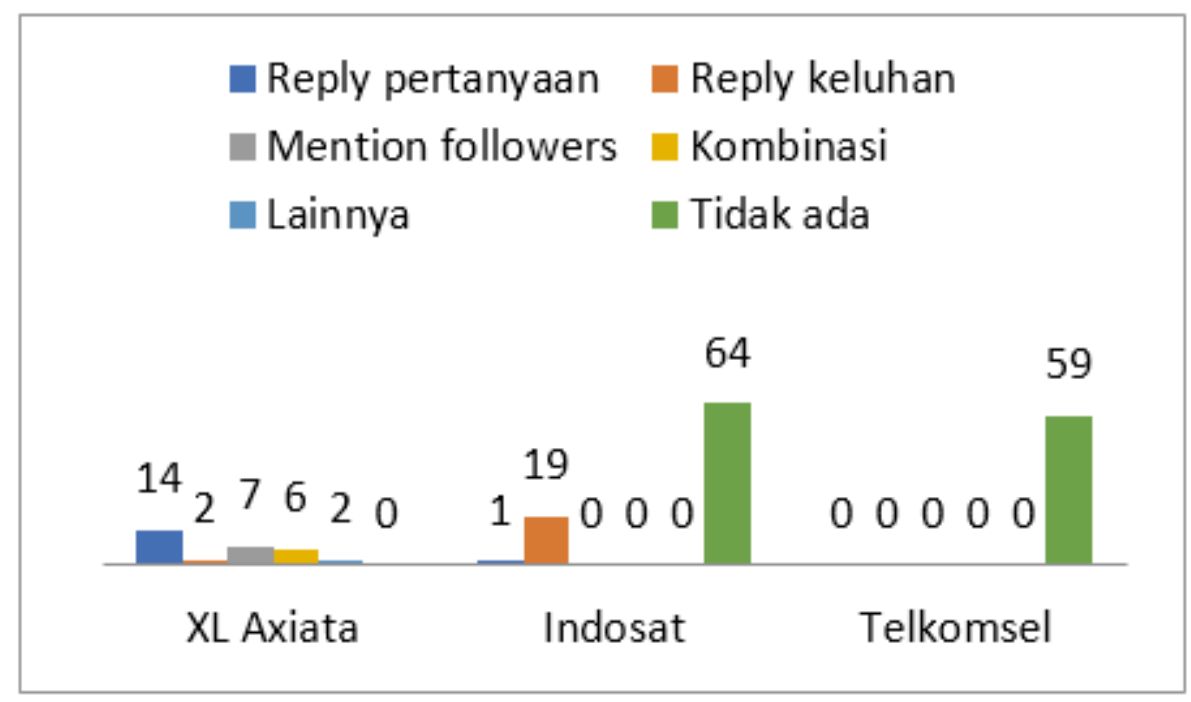

Sumber: Hasil olah data, 2019 
itu, penerapan praktik mutualitas kontrol ditunjukkan secara berbeda oleh akun@indosat dan@telkomsel. Respon yang diberikan oleh akun@indosat cenderung diberikan kepada sebagian publik saja, sedangkan @myXL berupaya merespon hampir seluruh pertanyaan yang diajukan. Di sisi lain, pola komunikasi yang disamapaikan akun@telkomsel cenderung berupa penyampaian informasi satu arah. Berkaca pada model praktik kehumasan yang dilakukan, model press agentry menjadi pola yang diterapkan pada proses komunikasi di akun ini. Lebih lanjut, ketiadaan respon organisasi terhadap komentar yang disampaikan publik mendorong terjadinya paracrisis yang berpotensi menjadi krisis yang lebih besar di masa depan.

Membandingkan Instagram sebagai media visual dan media tekstual lain seperti Twitter, mutualitas kontrol dalam proses komunikasi antara organisasi dan publik diterjemahkan secara berbeda. Dalam media tekstual seperti Twitter misalnya, mutualitas kontrol dapat dilakukan dalam bentuk pertanyaan yang diajukan kepada organisasi kemudian dibalas oleh organisasi menggunakan fitur reply. Pesan utama yang diperbincangkan berasal dari publik dan ditanggapi oleh organisasi. Organisasi diposisikan sebagai sosok yang lebih responsif terhadap arah pembicaraan yang diinisiasi oleh publik.
Dalam penelitian ini ditemukan bahwa proses mutualitas kontrol yang terjadi ditampilkan dalam bentuk yang sama sekali berbeda. Dalam media Instagram, organisasi justru nampak lebih aktif dalam mengirimkan pesan. Hampir tidak ditemukan dalam objek penelitian ini unggahan yang berasal dari publik dan diunggah ulang oleh organisasi dengan menggunakan fitur repost. Seluruh informasi cencerung didominasi oleh organisasi.

Kenihilan praktik mutualitas kontrol dalam hubungan organisasi dan publik sesungguhnya bukan sama sekali tidak bisa terjadi. Dalam cara sederhana, mutualitas kontrol dapat dilakukan dengan memanfaatkan fitur balas komentar yang ada di setiap unggahan. Masih terbatasnya organisasi yang memanfaatkan fitur ini untuk menjalin hubungan dengan publik kiranya dapat menjadi catatan untuk meningkatkan peran yang imbang antara organisasi dan publik dalam mengelola proses komunikasi yang terjadi.

Dimensi selanjutnya yang menandai hubungan organisasi dan publik adalah kepercayaan (trust). Dimensi kepercayaan mengindikasikan kepercayaan publik terhadap kredibilitas dan kualitas kinerja organisasi. Gagasan utama dalam dimensi ini berpusat pada keyakinan publik akan integritas, keandalan, dan kompetensi organisasi untuk menyelesaikan persoalan publik dan memenuhi ekspektasinya.

Dimensi kepercayaan agaknya masih 


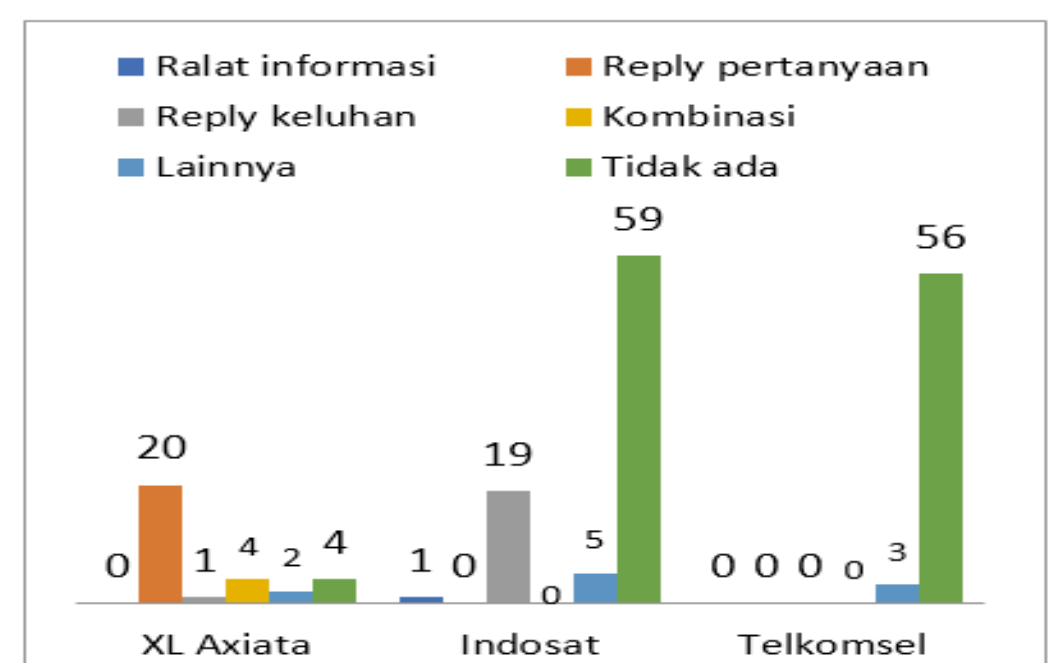

Sumber: Hasil olah data, 2019

\section{Gambar 2 Dimensi Kepercayaan}

dicerminkan dengan rendah dalam hubungan integritas organisasi dalam memberikan organisasi dan publik di ketiga organisasi. layanannya kepada publik. Kedua, keandalan Sebagaimana ditampilkan pada gambar 2, (dependability) dimana publik merasa bahwa cerminan dimensi kepercayaan dalam akun organisasi merupakan sosok yang dapat Instagram resmi organisasi kembali ditampilkan diandalkan untuk memenuhi kebutuhan secara beragam oleh masing-masing organisasi. mereka. Ketiga, kompetensi (competence) Praktik yang dilakukan akun Instagram yang berkaitan dengan keyakinan publik resmi ketiga organisasi dalam menjawab bahwa organisasi memiliki kapasitas untuk pertanyaan publik sesungguhnya tidak hanya memenuhi ekspektasi mereka melalui layanan mengindikasikan adanya mutualitas kontrol yang diberikan. Terpenuhinya ketiga aspek ini saja, melainkan juga dimensi kepercayaan. memungkinkan publik memiliki kepercayaan Dengan merespon pertanyaan atau keluhan atas kinerja organisasi yang baik. Upaya publik organisasi telah mampu menunjukkan kredibilitas dan keandalan dalam memenuhi harapan publik.

Gagasan utama dalam dimensi kepercayaan berpusat pada keyakinan publik terhadap tiga untuk membangun kepercayaan sendiri dapat diwujudkan dalam berbagai bentuk, misalnya dengan menjawab pertanyaan atau keluhan publik, serta memberikan ralat informasi. Dengan menjawab pertanyaan atau persoalan aspek yang harus dimiliki organisasi. Pertama, yang dihadapi publik maka organisasi dapat integritas (integrity) yang berkaitan dengan menunjukkan sisi keandalannya. Sementara 
itu, dengan memberikan ralat informasi sebagai contoh, maka organisasi dapat menunjukkan integritasnya. Pada akhirnya, seluruh upaya yang dilakukan organisasi bermuara pada persepsi publik bahwa organisasi mampu memenuhi ekspektasi mereka atas layanan yang baik.

Dimensi kepuasan menjadi penanda hubungan organisasi dan publik yang merujuk pada terpenuhinya kebutuhan dan keinginan publik dari organisasi, sehingga hubungan yang terjalin dianggap bermanfaat (beneficial) dan mampu memberikan kepuasan kepada publik.

Serupa dengan kedua dimensi sebelumnya, dimensi kepuasan juga menunjukkan indeks yang rendah. Mengacu pada data yang ditampilkan pada gambar 3 dapat disimpulkan bahwa mayoritas publik masih belum merasa puas dengan hubungan yang terbangun dengan organisasi. Lebih lanjut, rendahnya indeks kepuasan publik terhadap hubungannya dengan organisasi di media sosial agaknya tidak lepas dari sifat (nature) konsep kepuasan yang sulit dikaji dengan menggunakan metode analisis isi. Sifat dimensi kepuasan yang semestinya berpusat pada ekspresi kepuasan publik yang disampaikan kepada organisasi melalui media baru hanya dapat dimanifestasikan misalnya melalui fitur repost.

Dimensi komitmen sebagai penanda hubungan organisasi dan publik berkaitan dengan kesediaan kedua pihak saling menjaga dan meningkatkan kualitas hubungan mereka. Komitmen organisasi untuk menjalin hubungan dengan publik diaktualisasikan melalui berbagai bentuk. Meskipun demikian, berbeda dengan dimensi kepuasan yang cenderung berasal dari publik, maka dimensi komitmen idealnya

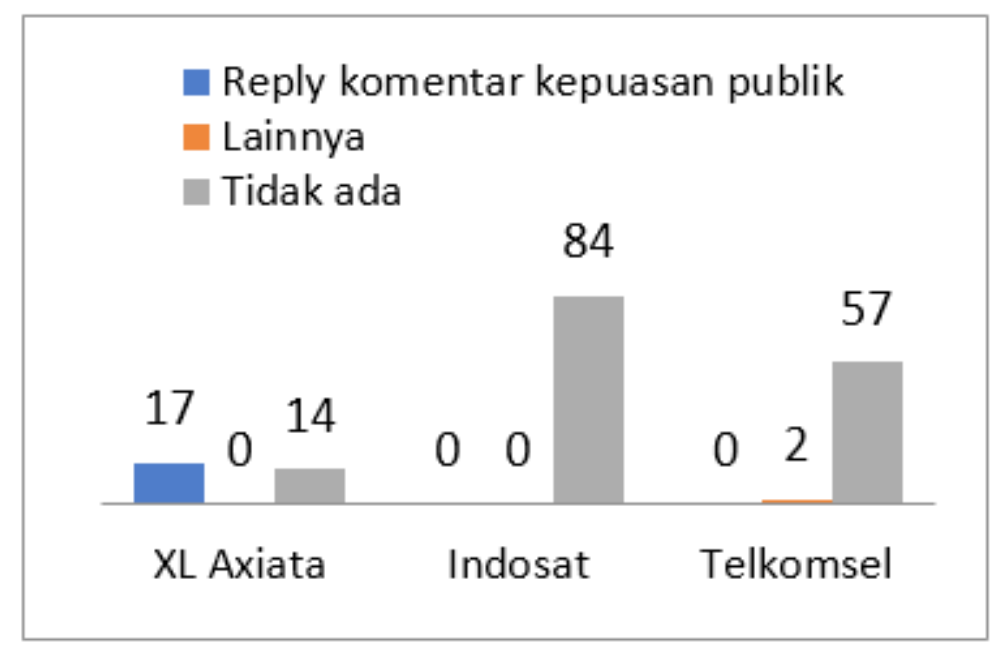

Sumber: Hasil olah data, 2019 


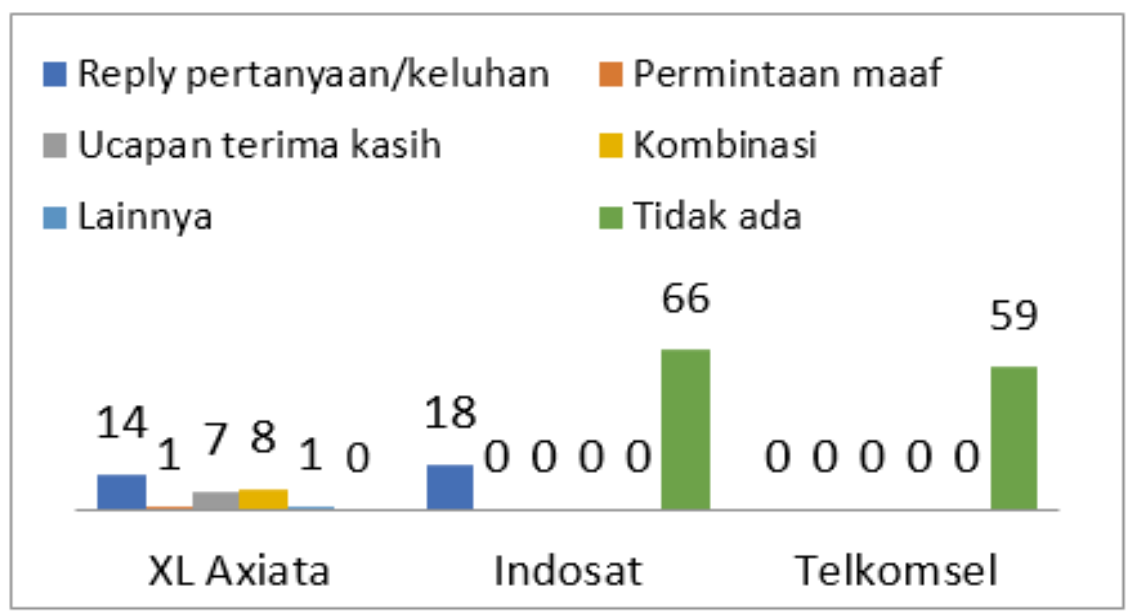

Sumber: Hasil olah data, 2019

\section{Gambar 4 Dimensi Komitmen}

berasal dari organisasi. Indikator komitmen dalam hubungan organisasi dan publik misalnya diwujudkan dalam bentuk apresiasi kepada publik atau permohonan maaf. Sementara itu, dalam tataran yang lebih tinggi komitmen organisasi untuk mengembangkan relasi dengan publik dapat diaktualisasikan dalam bentuk pemberian hadiah, ucapan selamat, atau komunikasi personal lain yang berpusat pada prinsip manajemen relasi konsumen.

Bentuk dimensi komitmen terbagi menjadi dua jenis yaitu continuance yang berkaitan dengan tindakan yang dilakukan organisasi dan publik, serta affective commitment yang berkaitan dengan aspek emosional yang ingin dibangun di antara organisasi dan publik. Sebagaimana ditampilkan dalam gambar 4, bentuk komitmen yang dijalankan cenderung didominasi oleh continuance commitment.
Lebih lanjut, bentuk komitmen yang diterapkan oleh organisasi dalam menjalin hubungan dengan publik pun relatif masih bersifat responsif. Minimnya dimensi komitmen dalam hubungan organisasi dan publik dapat dipahami sebagai kondisi yang berbanding lurus dengan kepuasan publik.

Mengilas balik hasil data sebelumnya yang menunjukkan masih rendahnya dimensi kepercayaan, komitmen, dan kepuasan sesungguhnya tidak dapat kita lihat secara parsial. Ketiga dimensi ini sesungguhnya memiliki hubungan yang linier, sehingga indeks rendah di salah satu dimensi sangat mungkin memengaruhi kedua dimensi lainnya. Lebih lanjut, ketiga dimensi ini pada galibnya akan bermuara pula pada bentuk hubungan yang dijalin oleh organisasi dan publik.

Hubungan organisasi dan publik dapat 


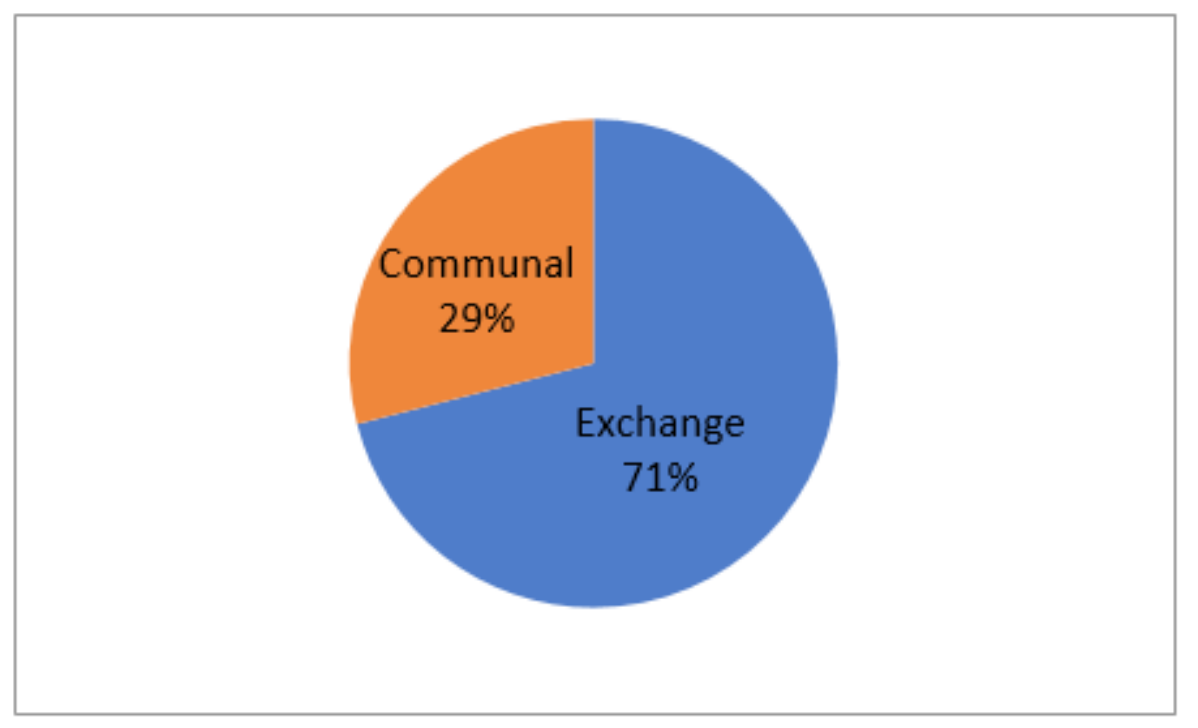

Sumber: Hasil olah data, 2019

Gambar 5 Luaran Hubungan Organisasi dan Publik

dipahami pula dari bentuk luaran hubungan yang dihasilkan. Luaran hubungan organisasi dan publik dapat mewujud dalam dua bentuk yaitu transaksional (exchange) dan komunal (communal). Membandingkan keduanya, hubungan komunal dianggap sebagai bentuk yang lebih ideal dalam mencerminkan hubungan organisasi dan publik. Meskipun demikian, pada praktiknya hubungan transaksional dan komunal kerap terjadi secara simultan.

Bentuk luaran hubungan organisasi dan publik di akun Instagram organisasi cenderung masih didominasi oleh bentuk transaksional (exchange relationship). Hubungan yang dibangun antara organisasi dan publik masih terbatas pada relasi produsen-konsumen yang memperhitungkan pada pengalaman transaksi di antara keduanya. Bentuk exchange relationship yang diaktualisasikan dalam hubungan organisasi dan publik cukup beragam. Meskipun demikian, praktik yang jamak dilakukan oleh ketiga akun Instagram resmi perusahaan penyedia jasa telekomunikasi seluler yang ditelaah dalam studi ini cenderung mengambil bentuk respon terhadap pertanyaan publik serta consumer rewards.

Hubungan transaksional yang terjalin antara organisasi dan publik dapat pula dipahami dalam perspektif cost-benefit analysis. Dalam perspektif ini organisasi dituntut untuk mampu mendengarkan, memahami, dan membangun dialog dengan publik sehingga nantinya organisasi dapat mereduksi potensi konflik yang mungkin muncul dari publik. Dalam perspektif 
kehumasan, gagasan ini sesungguhnya tidak berbeda dengan kerangka excellence theory yang menitikberatkan pada harmoni relasi antara organisasi dan publik. Melalui pandangan costbenefit analysis, hubungan organisasi dan publik diposisikan sebagai sebuah investasi masa depan. "Investasi" ini kiranya harus dipandang seragam oleh organisasi dan publik sebagai kondisi yang menguntungkan kedua pihak dan bukan hanya menguntungkan organisasi semata. Pemahaman publik akan keuntungan yang mungkin diperolehnya mendorong mereka untuk bersedia menjalin hubungan jangka panjang dengan organisasi.

Lebih lanjut, luaran hubungan dalam bentuk komunal cenderung masih ditampilkan secara terbatas dalam objek penelitian ini. Umumnya, hubungan dalam bentuk komunal dalam studi ini ditunjukkan dalam bentuk penyampaian sapaan (greeting), serta pembahasan tentang isu-isu kontemporer seperti teknologi digital, peristiwa terkini, serta tren milenial. Adapun luaran hubungan sesungguhnya tidak terbatas hanya pada dua bentuk yang digagas oleh Hon dan Grunig saja. Pada perkembangannya, eksplorasi atas kemungkinan bentuk-bentuk lain dalam hubungan organisasi dan publik mewujud dalam sejumlah alternatif seperti mutual komunal, konvenantal, kontraktual, simbiotik, manipulatif, dan eksploitatif. Bentuk-bentuk hubungan ini menjadi alternatif untuk melihat secara lebih spesifik hubungan transaksional atau komunal yang terjalin sesuai dengan level (degree) interaktivitas hubungan yang dibangun antara organisasi dan publik di media baru.

Kehadiran media sosial telah lama disikapi secara optimis sebagai peluang yang memungkinkan terwujudnya keseimbangan relasi yang saling menguntungkan antara organisasi dan publik. Arah komunikasi horizontal yang menjadi penciri utama media sosial dianggap mampu memediasi proses komunikasi yang egaliter. Meskipun demikian, optimisme atas gagasan ini disangsikan oleh sejumlah studi yang meyakini bahwa sepanjang organisasi tidak mengubah cara mereka berkomunikasi dan masih mengelola media baru dengan pola media konvensional maka keseimbangan relasi antara organisasi dan publik mustahil diwujudkan (Edman, 2010).

Catatan penting dari studi terdahulu dalam memahami hubungan organisasi dan publik mengerucut pada satu simpulan bahwa organisasi cenderung mengikuti tren media komunikasi yang berkembang, namun belum sungguh-sungguh menggunakannya sebagai medium untuk menjalin komunikasi dialogis dengan publik. Fenomena serupa agaknya ditemukan pula pada praktik penggunaan media sosial Instagram oleh akun resmi Instagram perusahaan penyedia jasa telekomunikasi. 
Berbeda dengan Facebook dan Twitter sebagai dua media komunikasi populer, Instagram merupakan media sosial yang secara spesifik menggunakan aspek visual sebagai basis konten dalam platform-nya. Umumnya, media komunikasi berbasis visual lebih tepat digunakan sebagai media untuk membentuk citra diri (brand image). Akan tetapi, bagi publik dimanapun mereka menemukan keberadaan brand di media sosial, mereka cenderung akan menggunakan medium tersebut untuk berkomunikasi dengan organisasi.

Perbedaan perspektif antara organisasi dan publik dalam memaknai media sosial berkonsekuensi terhadap hubungan yang dibangun. Organisasi yang cenderung latah mengadopsi tren media sosial populer sebagai media untuk membentuk citra diri tidak selaras dengan perspektif publik yang cenderung memosisikan seluruh kanal media komunikasi yang dimiliki organisasi sebagai fungsi layanan konsumen (customer care).

Empat dimensi yang diajukan Hon dan Grunig menjadi struktur yang digunakan untuk memahami hubungan organisasi dan publik di media sosial (Hon \& Grunig, 1999). Sebagai dimensi pertama, mutualitas kontrol idealnya bersifat resiprokal. Organisasi dan publik idealnya terlibat dalam diskusi aktif secara kontinyu dalam proses komunikasi yang terjadi. Akibatnya, mutualitas kontrol tidak bisa dilihat semata hanya sebagai adanya ruang bagi publik untuk didengar (to be heard), dijawab (to be answered), dan direspon (to be responded) oleh organisasi. Ketiadaan respon sebagai elemen utama dalam resiprositas proses komunikasi menyebabkan hubungan yang berorientasi pada upaya membangun proses komunikasi dialogis antara organisasi dan publik sulit diwujudkan.

Ketimpangan relasi kuasa di antara organisasi dan publik sesungguhnya merupakan hal yang lumrah. Hon dan Grunig melihat ketidakseimbangan ini sebagai hal lumrah, serta keseimbangan relasi yang benar-benar setara mustahil dilakukan (Hon \& Grunig, 1999). Meskipun demikian, stabilitas relasi antara organisasi dan publik dianggap menjadi titik tekan yang penting untuk menjamin hubungan organisasi dan publik yang harmonis.

Dimensi kepuasan sebagai elemen untuk menakar hubungan organisasi dan publik di media sosial tidak lepas dari pengaruh mutualitas kontrol. Ketidakseimbangan relasi antara organisasi dan publik dianggap sebagai hal yang lumrah, namun upaya untuk menyeimbangkan relasi kuasa di antara kedua pihak perlu diupayakan secara optimal. Ketimpangan kuasa hanya pada satu pihak dapat diasosiasikan dengan penurunan persepsi terhadap kompetensi komunikator dan kepuasan dalam hubungan, sehingga nantinya meningkatkan level aktivisme (Hon \& Grunig, 
1999).

Diskusi tentang rendahnya tingkat kepuasan publik terhadap perusahaan penyedia jasa layanan telekomunikasi seluler di Indonesia sesungguhnya bersifat multidimensional. Bangunan hubungan organisasi dan publik yang dianggap belum efektif diterapkan di media sosial bukan menjadi satu-satunya persoalan yang melandasi inefektivitas relasi. Diskusi tentang rendahnya tingkat kepuasan publik dapat diurai menjadi beberapa hal. Pertama, persoalan mendasar mungkin justru terletak pada kualitas produk/layanan yang diberikan oleh organisasi. Dibandingkan dengan negaranegara Asia Tenggara lainnya kecepatan koneksi internet di Indonesia masih dianggap rendah, sedangkan Indonesia merupakan negara tertinggi kelima di dunia dilihat dari jumlah penggua internetnya. Kondisi ini menyebabkan para pengguna internet di Indonesia kerap melakukan komplain kepada perusahaan penyedia jasa layanan telekomunikasi seluler.

Kedua, persoalan berpusat pada isu keberadaan (availability) media komunikasi yang dimiliki organisasi. Tidak dimungkiri bahwa media sosial merupakan cara tercepat, termudah, dan termurah bagi publik untuk menjangkau organisasi. Publik tidak perlu menunggu lamauntukmelakukan korespondensi dengan organisasi, tidak perlu mengeluarkan biaya besar untuk menelepon customer care, atau menempuh perjalanan untuk menjangkau kantor organisasi. Secara umum, publik mengakses akun Instagram organisasi untuk dua kemungkinan yaitu menyampaikan keluhan (fenomena "shitstorm") atau mendukung serta memuji kinerja organisasi (fenomena “candystorm”) (López-López, Ruiz-de-Maya, \& Warlop, 2014). Media sosial dianggap sebagai media komunikasi yang efektif bagi publik untuk mengungkapkan aspirasinya. Oleh karena itu, kehadiran organisasi di berbagai kanal media sosial sesungguhnya berpeluang menjadi harapan atas solusi persoalan publik, sekaligus menjadi pintu yang mempermudah publik menjangkau organisasi apabila dapat dimanfaatkan dengan baik.

Dimensi kepercayaan berkaitan dengan keyakinan publik terhadap organisasi. Hasil studi yang menunjukkan dimensi kepercayaan masih diterapkan secara terbatas dikaitkan dengan tema unggahan yang disampaikan organisasi di akun Instagramnya. Aspek integritas, keandalan, dan kompetensi organisasi sebagai tiga gagasan utama yang mempengaruhi kepercayaan publik terhadap organisasi agaknya belum mampu ditampilkan secara optimal dalam konten unggahan. Mayoritas tema yang disampaikan dalam unggahan cenderung didominasi oleh isu promosi (41\%), selain itu pola interaksi organisasi kepada publik pun cenderung masih bersifat responsif. 
Elemen kepercayaan sejatinya menjadi faktor krusial dalam proses membangun hubungan jangka panjang antara organisasi dan publik. Dimensi kepercayaan diyakini berkaitan dengan prinsip akuntabilitas dan transparansi dalam proses pengambilan keputusan, serta aktivitas operasional organisasi (Jahansoozi, 2007). Selain itu, peningkatan transparansi informasi berbanding lurus dengan meningkatnya kepercayaan publik terhadap organisasi sehingga mendorong adanya peluang kooperasi dan kolaborasi di antara keduanya.

Selanjutnya, dimensi komitmen yang masih ditampilkan secara rendah dalam hasil studi ini menunjukkan bahwa hubungan yang terjalin masih belum optimal. Padahal, sebagaimana disampaikan sebelumnya komitmen yang terbangun antara organisasi dan publik berpeluang untuk mereduksi potensi konflik di masa depan. Melihat kelindan relasi antara organisasi dan publik dalam perspektif cost-benefit analysis hubungan di antara kedua pihak dianggap sebagai sebuah "investasi” yang idealnya menguntungkan kedua pihak. Sebagai muara dari proses tersebut baik organisasi maupun publik sama-sama tidak keberatan untuk berkomitmen membangun hubungan jangka panjang.

Resiprositas menjadi aspek yang turut dikaji dalam studi ini. Resiprositas berkaitan dengan adanya respon dua arah yang diberikan oleh organisasi dan publik dalam proses komunikasi. Mengacu pada data studi, sebagian besar unggahan yang nampak di akun Instagram resmi organisasi sama-sama belum menunjukkan adanya proses komunikasi yang resiprokal. Ketiadaan timbal balik dalam proses komunikasi mendorong proses pengelolaan hubungan organisasi dan publik dalam model simetris dua arah sulit dilakukan.

Ketiadaan respon yang resiprokal dalam proses komunikasi antara organisasi dan publik turut mempengaruhi luaran bentuk hubungan. Luaran bentuk hubungan yang dibangun antara publik dan ketiga organisasi di media sosial Instagram sebagaimana menjadi hasil studi ini cenderung masih bersifat transaksional. Meskipun demikian, bentuk exchange relationship yang dibangun masih berpotensi untuk berkembang menjadi communal relationship ditilik dari bentuk jenis relasi yang dibangun. Terlebih, sejumlah organisasi telah menerapkan program berbasis pengelolaan relasi dan loyalitas konsumen seperti consumer rewards yang memungkinkan hubungan hubungan organisasi publik berkembang menjadi bentuk komunal.

Kehadiran kanal media komunikasi organisasi secara omnipresent menjadi konsekuensi yang tidak terelakkan sebagai hasil dari perkembangan teknologi dan peluang bagi publik untuk berkomunikasi secara langsung 


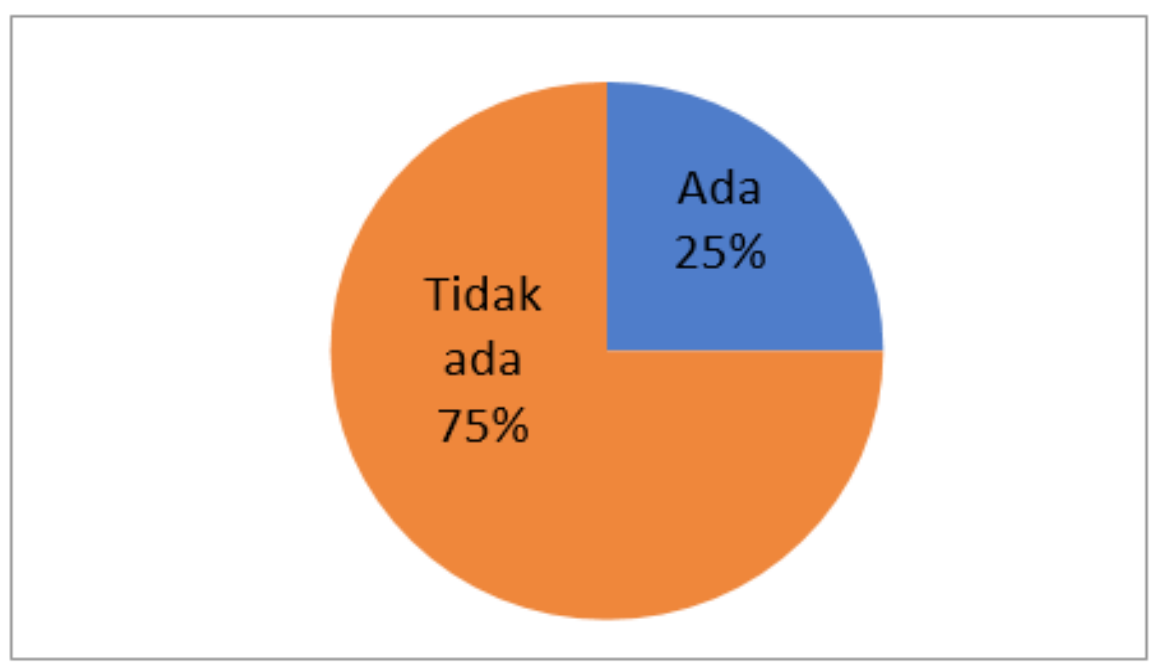

Sumber: Hasil olah data, 2019

\section{Gambar 6 Resiprositas dalam Unggahan}

dengan organisasi kapan pun dan dimana pun (Rangaswamy \& Bruggen, 2005). Dalam kerangka fungsi public relations untuk menjaga hubungannya dengan publik, konsep omnichannel environemnt dapat dipahami sebagai upaya organisasi untuk memaksimalkan kualitas hubungannya dengan publik. Konsep omnichannel sendiri dipaparkan sebagai manajemen sinergis seluruh kanal komunikasi pemasaran yang dimiliki organisasi sehingga berdampak optimal. Oleh karena itu, prinsip manajemen sinergis di antara berbagai kanal komunikasi organisasi termasuk akun Instagram resmi organisasi harus dipahami sebagai langkah penting yang bertujuan untuk memaksimalkan hubungan organisasi dan publik yang dijalin.

Dalam upaya memaksimalkan hubungan organisasi dan publik agaknya keempat dimensi konsep hubungan yang digagas oleh Hon dan Grunig perlu dikaji kembali. Dalam perspektif ekonomi, Morgan dan Hunt menyebutkan bahwa proses mempertahankan konsumen semestinya bisa lebih murah dibandingkan menarik konsumen baru (Morgan \& Hunt, 1994). Akan tetapi, biaya ekonomi yang dikeluarkan agaknya tidak berbanding lurus dengan upaya komunikasi yang dilakukan. Upaya mempertahankan konsumen mungkin saja lebih murah, namun tidak lebih mudah. Dalam upaya mempertahankan konsumen, organisasi dituntut mampu mempertahankan kepercayaan dan komitmen konsumen, sedangkan bagi publik kedua hal tersebut dapat terpenuhi apabila terdapat mutualitas kontrol dan kepuasan terhadap layanan organisasi. Akibatnya, keempat dimensi perlu dipenuhi 
seluruhnya sebagai prasyarat atas konstruksi hubungan organisasi dan publik yang kuat.

Mengacu pada hasil studi ini nampak bahwa praktik penggunaan Instagram sebagai kanal komunikasi yang dilakukan organisasi merujuk pada satu simpulan, one size doesn't fit all. Meskipun ketiga bidang industri bergerak pada ranah bidang industri yang sama dengan model bisnis serupa, namun cara mereka berkomunikasi dengan publik menggunakan Instagram sangat berlainan. Perbedaan ini terutama dapat diidentifikasi jelas dengan menelaah pola komunikasi setiap organisasi yang dicerminkan dalam setiap dimensi.

Perbedaan cara setiap organisasi menggunakan Instagram untuk berkomunikasi dengan publik turut memengaruhi pemosisian Instagram dalam strategi media komunikasi organisasi. Mengacu pada hasil studi ini, akun @myXL cenderung lebih banyak menggunakan Instagram media untuk berdialog dengan publik, khususnya sebagai fungsi layanan konsumen (customer care service). Pola berbeda ditampilkan oleh akun@indosat yang cenderung menempatkan Instagram sebagai media komunikasi untuk membentuk citra diri organisasi. Meskipun akun@indosat turut merespon pertanyaan publik di Instagram, namun pola komunikasi @indosat yang menyarankan publik untuk menghubungi akun Twitter resmi organisasi menegaskan bahwa
Instagram memang bukan diposisikan sebagai fungsi penanganan konsumen. Dalam konteks omni-channel marketing, sesungguhnya praktik ini mampu menunjukkan penggunaan berbagai kanal komunikasi pemasaran secara bersamaan dan beriringan, namun memiliki fungsi masing-masing. Lebih lanjut, pola serupa agaknya diterapka pula oleh akun@telkomsel yang cenderung menempatkan Instagram sepenuhnya hanya pada fungsi pembentukan citra dan diseminasi informasi korporat. Perbedaan penerapan praktik komunikasi antara organisasi dan publik ketiga organisasi di akun Instagram resmi mereka menggarisbawahi satu simpulan bahwa tidak ada strategi yang berlaku mutlak bahkan bagi organisasi-organisasi yang bergerak pada satu bidang industri yang sama.

\section{SIMPULAN}

Kecenderungan organisasi untuk menggunakan platform media baru yang tengah populer kerap berujung pada kelatahan mengikutitren. Dalamperspektifbrand presence kehadiran organisasi di berbagai kanal media baru kiranya berdampak positif pada brand awareness. Meskipun demikian, dalam konteks pengelolaan hubungan organisasi dan publik, konsep brand presence tidak bisa diterapkan secara sembarangan. Kemunculan brand secara massif di ruang publik saja dianggap tidak cukup karena dibutuhkan kemampuan untuk 
mengembangkan hubungan organisasi dan publik yang efektif. Pada kondisi terburuk, praktik penggunaan kanal media baru secara tidak tepat justru berpotensi menyebabkan back fire bagi organisasi.

Fokus studi ini berupaya untuk menakar dan memetakan bentuk hubungan organisasi dan publik yang termanifestasi dalam konten unggahan di akun Instagram resmi tiga perusahaan telekomunikasi. Sebagaimana ditampilkan dalam hasil studi ini, takaran atas hubungan organisasi dan publik di akun Instagram resmi ketiga organisasi cenderung masih rendah. Bentuk hubungan yang terjadi cenderung didominasi oleh organisasi dan kurang menitikberatkan pada aspek dialogis serta interaktivitas dengan publik. Muara akar persoalan dari belum optimalnya penggunaan media sosial Instagram oleh ketiga organisasi berakar pada perbedaan perspektif antara organisasi dan publik dalam memaknai Instagram sebagai media komunikasi korporat. Organisasi cenderung memaknai Instagram sebagai media sosial populer yang digunakan untuk membangun citra diri perusahaan (brand image), sedangkan publik secara berbeda cenderung memaknainya sebagai media untuk menangani keluhan konsumen (customer care). Perbedaan perspektif ini menyebabkan perbedaan pola interaksi dan substansi pesan yang disampaikan. Kontradiksi antara kedua perspektif pada akhirnya justru memberikan dampak kerugian baik bagi organisasi maupun publik. Organisasi yang mulanya memosisikan Instagram sebagai media untuk membangun citra justru kesulitan untuk membentuk citra positif tersebut terlebih kala publik "menyerang" organisasi dengan komentar buruk terhadap organisasi yang dianggap abai terhadap publik. Di sisi lain, publik juga mengalami kerugian karena persoalan yang mereka hadapi berkaitan dengan layanan organisasi tidak dapat teratasi dengan baik.

Perbedaan cara pandang dalam praktik penggunaan Instagram sebagai media komunikasi korporat juga dilakukan secara berbeda oleh ketiga organisasi yang berada di bidang industri yang sama. Meskipun ketiga organisasi bergerak pada bidang yang sama namun penerapan Instagram yang dilakukan relatif berbeda. Perbedaan signifikan terutama berkaitan dengan kesigapan organisasi dalam merespon komentar yang disampaikan oleh publik di fitur komentar unggahannya. Di antara ketiga akun yang menjadi objek studi dalam penelitian ini baru sebagian saja yang memberikan respon pada komentar publik pun dalam level yang berbeda.

Meskipun demikian, kesamaan di antara ketiga akun merujuk pada satu benang merah yang menunjukkan bahwa ketiga akun organisasi cenderung mengindikasikan 
satu kondisi yang sama yakni memosisikan Twitter sebagai media utama dalam mengelola keluhan konsumen. Media berbasis tekstual dianggap lebih akomodatif terhadap kebutuhan penanganan konsumen di media baru.

Pengelolaan hubungan organisasi dan publik yang termediasi di media baru membutuhkan adanya struktur bangunan yang kokoh. Rekomendasi pengembangan kajian konseptual dengan mengembangkan model hubungan organisasi dan publik yang sesuai dengan karakteristik media komunikasi berbasis visual menjadi langkah yang dapat dilakukan untuk mengembangkan kajian di bidang ini. Secara akademik, pengembangan model hubungan organisasi dan publik yang selaras dengan karakteristik platform memungkinkan pengukuran relasi menjadi lebih tepat. Secara praktikal, pengembangan model ini dapat menjadi panduan bagi praktisi kehumasan untuk memperhatikan dimensi-dimensi yang penting guna menciptakan hubungan organisasi dan publik yang menguntungkan kedua pihak secara simetris.

\section{DAFTAR PUSTAKA}

Cutlip, S. M., Center, A. H., \& Broom, G. M. (2009). Effective public relations (9th ed.). New Jersey: Prentice-Hall. Inc.

Edman, H. (2010). Twittering to the top: $A$ content analysis of corporate tweets to measure organization- public relationships. Louisiana State University. Retrieved from https:// digitalcommons.1su.edu/cgi/viewcontent. cgi article $=2725 \&$ context $=$ gradschool_ theses

Grunig, J. E. (2009). Paradigms of global public relations in an age of digitalisation. PRism, 6(2), 1-19. Retrieved from http://praxis. massey.ac.nz/prism_on-line_journ.html

Hon, L. C., \& Grunig, J. E. (1999). Guidelines measuring relationships in public relations: Gold standard paper of the Commission on Public Relations Measurement \& Evaluation. Florida.

J.Jussilaa, J., Kärkkäinena, H., \& HeliAramoImmonenb. (2014). Social media utilization in business-to-business relationships of technology industry firms. Computers in Human Behavior, 30(1), 606-613. https://doi.org/https://doi.org/10.1016/j. chb.2013.07.047

Jahansoozi, J. (2007). Julia jahansoozi. Public Relations Review, 33(4), 398-406. https://doi.org/https://doi.org/10.1016/j. pubrev.2007.08.006

Jahn, K., \& Nielsen, P. A. (2011). A vertical approach to knowledge management: Codification and personalization in software processes. International Journal of Human Capital and Information Technology Professionals, 2(2), 26-36.

Lee, E., Moon, J. H., Lee, J.-A., \& Sung, Y. (2015). Pictures speak louder than words: Motivations for using Instagram. Cyberpsychology Behavior of Social Network, 18(9), 552-556.

López-López, I., Ruiz-de-Maya, S., \& Warlop, L. (2014). When sharing consumption emotions with strangers is more satisfying than sharing them with friends. Journal of Service Research, 
17(1), 475-488. https://doi.org/https://doi. org/10.1177/1094670514538835

Men, L. R., \& Tsai, W. (2014). Perceptual, attitudinal, and behavioral outcomes of organization-public engagement on corporate social networking sites. Journal of Public Relations Research, 26(5), 417435. https://doi.org/https://doi.org/10.1080 /1062726X.2014.951047

Morgan, R. M., \& Hunt, S. D. (1994). The commitment-trust theory of relationship marketing. Journal of Marketing, 58(3), 20. https://doi.org/10.2307/1252308

Muntinga, D. G., Moorman, M., \& Smit, E. G. (2011). Introducing COBRAs: exploring motvations of brand-related social media use. International Journal of Advertising, 3(1), 13-46.

Putri, N. E., Hakim, N., \& Yamin, M. (2016). Ecologicall footprint and biocapacity analysis for flooding prevention in south sumatera. Jurnal Mimbar, 32(1), 58-64.

Rangaswamy, A., \& Bruggen, G. H. Van. (2005). Opportunities and challenges in multichannel marketing: An introduction to the special issue. Journal of Interactive Marketing, 19(2), 5-11.

Richardson, A., Ganz, O., \& Vallone, D. (2014). The cigar ambassador: how snoop dogg uses instagram to promote tobacco use. Tobacco Control, 23(1), 79-80.

Russmann, U., \& Svensson, J. (2016). Studying organizations on instagram. Information (Switzerland), 7(4), 1-12. https://doi. org/10.3390/info 7040058

Schill, D. (2012). The visual image and the political image: A review of visual communication research in the field of political communication. Review Communication, 12(2), 118-142.

Smith, L. R., \& Sanderson, J. (2015). I'm going to instagram it! an analysis of athlete selfpresentation on instagram. Journal of Broadcasting and Electronic Media, 59(2), 342-358. https://doi.org/10.1080/0883815 1.2015 .1029125

Tania, S. (2015). Public relations dalam media baru. Universitas Gadjah Mada. 